\title{
Overexpression of a Chitinase Gene from the Thermophilic Fungus, Thermomyces lanuginosus in Saccharomyces cerevisiae and Characterization of the Recombinant Chitinase
}

\author{
M. Prasad and P. Palanivelu*
}

Department of Molecular Microbiology, School of Biotechnology, Madurai Kamaraj University, Madurai, India

\begin{abstract}
A chitinase gene from the thermophilic fungus, Thermomyces lanuginosus ATCC 44008 has been cloned and overexpressed in Saccharomyces cerevisiae SEY 2101. The recombinant chitinase was produced as soluble secreted protein. The enzyme activity was found to be maximum on fourth day at $30^{\circ} \mathrm{C}$ in the induction medium. The overexpressed chitinase displayed optimum activity at $\mathrm{pH} 6.5$ and $a 0^{\circ} \mathrm{C}$. The recombinant chitinase attributed remarkable thermostability by holding more than $60 \%$ of the enzyme activity after $6 \mathrm{~h}$ at $50^{\circ} \mathrm{C}$. The molecular mass of the overexpressed chitinase was $42 \mathrm{kDa}$ as measured by SDS-PAGE. The kinetic parameters such as $K_{\mathrm{M}}$ and $V_{\max }$ of the enzyme were found to be $0.147 \mathrm{mM}$ and $814 \mathrm{mmoles} / \mathrm{min} / \mathrm{mg}$ protein, respectively. Synthesis of the recombinant chitinase was strongly repressed by glucose. The eukaryotic translational inhibitor, cycloheximide in the induction medium showed $10 \%$ of higher activity whereas $30 \%$ of the activity was inhibited by transcriptional inhibitors, viz. 8-azaguanine and 8-hydroxyquinoline. The overexpressed recombinant chitinase may find potential application in pharmaceutical industry to prepare chitooligosaccharides.
\end{abstract}

Keywords: Saccharomyces cerevisiae; Thermomyces lanuginosus; Recombinant chitinase; Overexpression; Thermostability; Chitooligosaccharides

\section{Introduction}

Chitin is one of the most abundant renewable biopolymers on the biosphere. It is the primary structural component of fungal cell walls and arthropod exoskeletons. Chitin is the homopolymer of $\beta-1$, 4 linked $\mathrm{N}$-acetyl glucosamine [1]. Chitinases are the enzymes which involve in the degradation and effective recycling of insoluble chitin in nature by hydrolyzing the $\beta-1,4$ glycosidic linkages. Based on amino acid sequences of the catalytic domains, chitinases are classified into two phylogenetically distinct families (GH18 and GH19), which are evolutionarily unrelated and have variations in protein sequence and structure [2]. Chitinases are ubiquitous and found in a broad range of taxons with diversified functions [3]. There are many reports on the controlled expression of microbial chitinases with chitin or its oligomers as inducers and glucose as repressor [4].

In the recent years, thermostable enzymes isolated from thermophilic microorganisms have gained wide industrial, medical, environmental and biotechnological applications due to their inherent stability to high temperatures and wide range of $\mathrm{pH}$ optima [5]. They have many advantages including reducing the risk of contamination by mesophilic microorganisms, higher process yield due to increased solubility of substrates and products [6]. Thermostable chitinases are required to digest the chitin at higher temperatures due to the crystalline nature of the chitin [7]. Thermostable chitinases have been isolated from hyperthermophilic archaeon such as Thermococcus chitonophagus [8], Thermococcus kodakaraensis [9] and Pyrococcus furiosus [10] and thermophilic bacteria such as Aeromonas sp [11], Bacillus sp [12-15], Clostridium thermocellum [16], Microbispora sp [17], Paenibacillus sp [18], Streptomyces thermoviolaceus [19]. However, there are only limited reports on chitinases from the thermophilic fungi [20-22].

Molecular cloning and characterization of the chitinase gene from the thermophilic fungus, Thermomyces lanuginosus ATCC 44008 was established by Palanivelu and Lakshmi (in press). The thermophilic fungal chitinase gene was cloned into a yeast centromeric plasmid, pLC9 under the control of sucrose promoter and transformed into Saccharomyces cerevisiae SEY 2101 ( $\left.\mathrm{YT}_{0}\right)$. Among the 11 transformants obtained, two of them (YT \& $\mathrm{YT}_{8}$ ) were growing also on chitin containing media and zone of clearance was found on chitin agar plate. These two strains were further analyzed and found that $\mathrm{YT}_{5}$ produced tremendous quantity of chitinase and $99.9 \%$ of the enzyme was secreted into the culture medium (unpublished data). This communication describes in details further characterization of the yeast transformant, $\mathrm{YT}_{5}$ and properties of the recombinant chitinase.

\section{Materials and Methods}

\section{Chemicals, strains and plasmids}

Chitin, $\rho$-nitrophenol, 4-Nitrophenyl- $\beta$-D- $N, N^{\prime}$-diacetylchitobiose, dimethyl sulfoxide, bovine serum albumin, 8 -azaguanine, cycloheximide and Trichoderma viride chitinase were purchased from Sigma Aldrich Chemical Company, USA. All other chemicals used were of analytical grade purchased from Indian manufacturers. The auxotrophic, sucrose mutant strain $\mathrm{YT}_{0}$ (Genotype: MAT a, Ura 3-52, leu 2-3, leu 2-112, Ade 2, Suc 2- $\Delta 9$ ) and the shuttle vector, pLC9 that harbours the SUC2 gene from Saccharomyces cerevisiae were kindly provided by Prof. Del Castillo Agudo, University of Valencia, Spain.

The chitinase gene sequence of T. lanuginosus ATCC 44008 has been deposited in GenBank and the GenBank accession number is JQ801444.

*Corresponding author: P. Palanivelu, Department of Molecular Microbiology, Schoo of Biotechnology, Madurai Kamaraj University, Madurai, India, Tel: 0452-2458208, 9486209859; Fax: 0452-2459105; E-mail: PP@mrna.tn.nic.in/ ppmkupp@gmail.com

Received May 01, 2012; Accepted June 14, 2012; Published June 20, 2012

Citation: Prasad M, Palanivelu P (2012) Overexpression of a Chitinase Gene from the Thermophilic Fungus, Thermomyces lanuginosus in Saccharomyces cerevisiae and Characterization of the Recombinant Chitinase. J Microb Biochem Technol 4: 086-091. doi:10.4172/1948-5948.1000076

Copyright: $\odot 2012$ Prasad M, et al. This is an open-access article distributed unde the terms of the Creative Commons Attribution License, which permits unrestricted use, distribution, and reproduction in any medium, provided the original author and source are credited 
Citation: Prasad M, Palanivelu P (2012) Overexpression of a Chitinase Gene from the Thermophilic Fungus, Thermomyces lanuginosus in Saccharomyces cerevisiae and Characterization of the Recombinant Chitinase. J Microb Biochem Technol 4: 086-091. doi:10.4172/19485948.1000076

\section{Growth of Saccharomyces cerevisiae and induction of recombinant chitinase}

The yeast strains, $\mathrm{YT}_{0}$ and $\mathrm{YT}_{5}$ were cultured in YEPD medium ( $1 \%$ yeast extract, $1.5 \%$ mycological peptone, $2 \%$ dextrose and agar $2 \%$ for plates) containing the supplements (Adenine, Leucine and Uracil at $40 \mu \mathrm{g} / \mathrm{ml}$ ) at $30^{\circ} \mathrm{C}$ for about $12-16 \mathrm{~h}$. Minimal medium containing different carbohydrates were used to study the expression of recombinant chitinase as reported by Delgado et al. [23] with minor modifications. The minimal medium contained $0.17 \%$ yeast nitrogen base, $0.5 \%\left(\mathrm{NH}_{4}\right)_{2} \mathrm{SO}_{4}$ and the supplements, $\mathrm{pH}$ 6.5. For chitinase induction, $0.2 \%$ colloidal chitin or $2 \%$ sucrose was used as sole carbon source. Colloidal chitin was prepared according to Sandhya et al. [24].

\section{Effect of carbon sources on the production of recombinant chitinase}

Effect of various carbon sources on the growth and production of chitinase by the $\mathrm{YT}_{5}$ and $\mathrm{YT}_{0}$ were studied in $25 \mathrm{ml}$ minimal medium containing the supplements as stated above and $2 \%$ glucose or $2 \%$ sucrose or $0.2 \%$ colloidal chitin for 7 days by continuous shaking of $180 \mathrm{rpm}$ at $30^{\circ} \mathrm{C}$. From each culture, the samples were collected at $24 \mathrm{~h}$ intervals and the growth was measured at $600 \mathrm{~nm}$. Then the cultures were centrifuged at $6000 \mathrm{rpm}$ for $10 \mathrm{~min}$ at $4^{\circ} \mathrm{C}$ and the clear supernatants were used as the enzyme source to quantify the chitinase activity.

\section{Assay of chitinase activity and protein estimation}

The chitinase activity was quantified using 4 -Nitrophenyl- $\beta-D-N$, $N$ '-diacetylchitobiose as substrate. The substrate $(2.5 \mathrm{mg} / \mathrm{ml})$ was prepared in dimethyl sulfoxide and in $100 \mathrm{mM}$ phosphate buffer, $\mathrm{pH} 6.5$ [25]. The assay was carried out according to instructor's manual (Sigma, CS0980) and Chernin et al. [26] with few modifications. The reaction mixture in a total volume of $100 \mu \mathrm{l}$ contained $20 \mu \mathrm{l}$ substrate $(50 \mu \mathrm{g} /$ $\mathrm{ml}$ ) with $10 \mu \mathrm{l}$ enzyme in $70 \mu \mathrm{l}$ assay buffer. The tubes were incubated for $30 \mathrm{~min}$ at $37^{\circ} \mathrm{C}$ and the reaction was stopped by the addition of $900 \mu \mathrm{l}$ of $4 \% \mathrm{Na}_{2} \mathrm{CO}_{3}$. The absorbancy was measured at $405 \mathrm{~nm}$ and activity was calculated based on $\rho$-nitrophenol standard. One unit (U) of the enzyme activity is defined as one $\mu$ mol of $\rho$-nitrophenol released per minute under standard assay conditions. Protein concentrations were estimated by Bradford's method with bovine serum albumin as standard [27].

\section{Effects of $\mathrm{pH}$ and temperature on recombinant chitinase activity}

The effect of $\mathrm{pH}$ on chitinase activity was studied in the $\mathrm{pH}$ ranges between 4.0 and 8.0 using $100 \mathrm{mM}$ acetate buffer ( $\mathrm{pH} 4.0$ to 6.0) and $100 \mathrm{mM} \mathrm{Na}-\mathrm{K}$ phosphate buffer ( $\mathrm{pH} 6.0$ to 8.0 ). The $\mathrm{pH}$ stability was studied by precipitating $1.0 \mathrm{ml}$ of enzyme samples with $\left(\mathrm{NH}_{4}\right)_{2} \mathrm{SO}_{4}$ at $90 \%$ saturation on ice. After 30 min the pellets were collected by centrifugation at $12,000 \mathrm{rpm}$ for $15 \mathrm{~min}$ at $4^{\circ} \mathrm{C}$. The pellets were resuspended in equal volume of buffers of different pHs $4.0-8.0$ then stored at $4^{\circ} \mathrm{C}$. Chitinase activity was measured once in 7 days for three weeks and compared with the control for relative stability.

The chitinase activity was assayed at different temperatures between $30^{\circ} \mathrm{C}$ and $70^{\circ} \mathrm{C}$ with the interval of $10^{\circ} \mathrm{C}$ to investigate the optimum temperature for activity of the enzyme. Thermostability of the enzyme was determined at $50^{\circ} \mathrm{C}$ at different time points for up to 6 $\mathrm{h}$ and compared with the control and commercial Trichoderma viride chitinase under standard assay conditions.

\section{Effect of substrate concentration and kinetic parameters}

The initial velocity of the enzyme reaction was determined using different substrate concentrations between $2.5 \mu \mathrm{g} / \mathrm{ml}$ and $125 \mu \mathrm{g} / \mathrm{ml}$ under standard assay conditions. The chitinase activity versus substrate concentration was plotted and $V_{\text {max }}, K_{\mathrm{M}}$ values were calculated from Lineweaver-Burk plot using Sigma Plot (systat software Inc. USA).

\section{SDS - PAGE analysis}

The expression of the induced recombinant chitinase was analyzed by SDS-PAGE [28]. The culture filtrates were precipitated with 2 volumes of cold acetone on ice for $15 \mathrm{~min}$ and centrifuged at 12,000 rpm for $15 \mathrm{~min}$ at $4^{\circ} \mathrm{C}$. The pellet was air-dried and resuspended in Milli Q water. The protein samples were boiled for $5 \mathrm{~min}$ with sample loading buffer. The proteins were distinguished in $10 \%$ polyacrylamide gel and stained overnight with Coomassie brilliant blue R-250. After destaining, the gel was documented.

\section{Effect of eukaryotic inhibitors on chitinase expression}

The regulation of the recombinant chitinase expression from $\mathrm{YT}_{5}$ culture was studied with transcriptional inhibitors, 8-hydroxyquinoline (10 and $100 \mu \mathrm{g} / \mathrm{ml})$ and 8 - azaguanine $(250 \mu \mathrm{g} / \mathrm{ml})$ and a translational inhibitor, cycloheximide (CHI) at 50 and $100 \mu \mathrm{g} / \mathrm{ml}$. The inhibitors were added to the induction medium and the culture was grown at $30^{\circ} \mathrm{C}$ in rotary shaker at $180 \mathrm{rpm}$ for four days. Control was maintained without inhibitor. The growth of the culture at $600 \mathrm{~nm}$, protein concentration and chitinase activity were assessed.

\section{Results}

\section{Overexpression and repression of recombinant chitinase in S. cerevisiae}

The transformed $\mathrm{YT}_{5}$ and nontransformed $\mathrm{YT}_{0}$ yeast strains were characterized for its growth on chitin as sole carbon source and production of chitinase and protein yeilds in the culture supernatant fluids. The $\mathrm{YT}_{5}$ and $\mathrm{YT}_{0}$ strains were grown in the induction medium and found that the $\mathrm{YT}_{0}$ unable to grow significantly due to its inability to utilize colloidal chitin as sole carbon source (Figure 1). The recombinant chitinase was overexpressed by $\mathrm{YT}_{5}$ in the minimal medium containing $0.2 \%$ colloidal chitin and maximum activity was found on fourth day. No significant chitinase activity was observed in the $\mathrm{YT}_{0}$ (Figure 2) also shows that the protein profiles in the culture supernatant fluids of both the $\mathrm{YT}_{5}$ and $\mathrm{YT}_{0}$ yeast strains. Maximum protein yield was detected on the third day of the $\mathrm{YT}_{5}$ culture and no significant amount of protein was found in the $\mathrm{YT}_{0}$. The maximum chitinase activity of $191.12 \mathrm{U} / \mathrm{ml}$ and $528.52 \mathrm{U} / \mathrm{ml}$ was detected in $2 \%$ sucrose and $0.2 \%$ colloidal chitin containing medium, respectively on fourth day (Figure 3). The overexpressed recombinant chitinase was found to be strongly repressed by glucose. The minimal medium with $2 \%$ glucose produced only $1.8 \%$ of the chitinase activity. In the presence of glucose, $\mathrm{YT}_{5}$ growth was found to be more than threefold higher than chitin induced culture. However, very little protein was found in the culture supernatant as compared to the chitin induced culture (Table 1).

\section{Effect of $\mathbf{p H}$ and $\mathrm{pH}$ stability of chitinase activity}

The effect of $\mathrm{pH}$ on chitinase activity from the $\mathrm{YT}_{5}$ culture was studied. The chitinase activity exhibited optimum at $\mathrm{pH} 6.5$ under standard assay conditions (Figure 4). Effect of $\mathrm{pH}$ on the enzyme stability was studied between $\mathrm{pH} 4.0$ and 8.0. The enzyme was found to be stable in a wide range of pHs from 4.0 to 8.0 for 21 days (data 
Citation: Prasad M, Palanivelu P (2012) Overexpression of a Chitinase Gene from the Thermophilic Fungus, Thermomyces lanuginosus in Saccharomyces cerevisiae and Characterization of the Recombinant Chitinase. J Microb Biochem Technol 4: 086-091. doi:10.4172/19485948.1000076

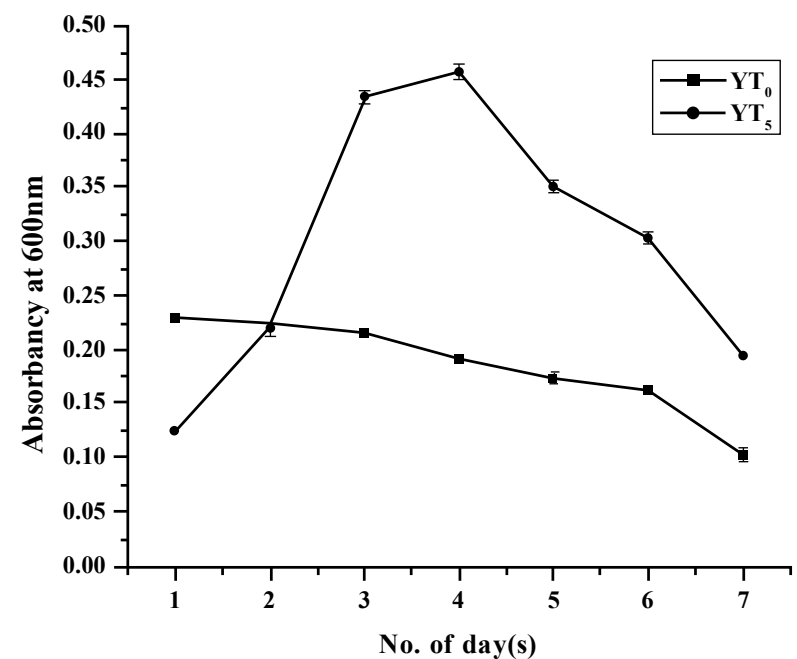

Figure 1: Growth of $\mathrm{YT}_{0}$ and $\mathrm{YT}_{5}$ in minimal medium containing $0.2 \%$ colloidal chitin.

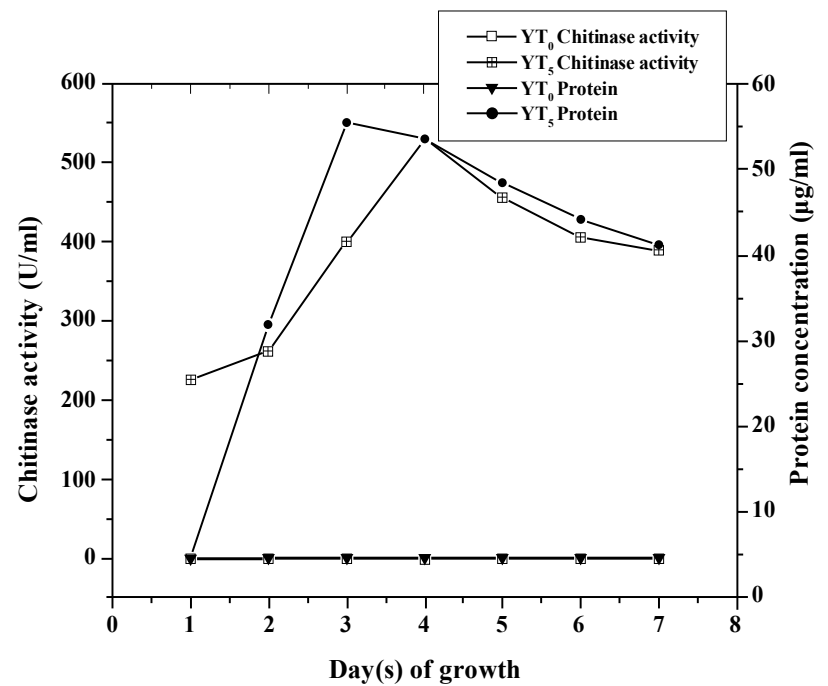

Figure 2: Recombinant chitinase activity and protein concentrations in $\mathrm{YT}_{0}$ and $\mathrm{YT}_{5}$.

not shown) and therefore, the enzyme can be stored at $4^{\circ} \mathrm{C}$ without significant loss of its activity.

\section{Effect of temperature and thermostability of chitinase activity}

The optimum temperature of the recombinant chitinase activity was examined between $30^{\circ} \mathrm{C}$ and $70^{\circ} \mathrm{C}$ and maximum activity was found at $60^{\circ} \mathrm{C}$. About $50 \%$ of the activity was detected at $30^{\circ} \mathrm{C}$ whereas more than $65 \%$ of the activity was observed at $70^{\circ} \mathrm{C}$ (Figure 5). The thermostability of the enzyme was analyzed at $50^{\circ} \mathrm{C}$ for $6 \mathrm{~h}$. As a result, $90.1 \%$ of the activity was found after $60 \mathrm{~min}$ and about $70 \%$ of the activity persisted after $3 \mathrm{~h}$ and after $6 \mathrm{~h}$, more than $60 \%$ of the activity was detected. When compared to commercially available T. viride chitinase, recombinant chitinase from $\mathrm{YT}_{5}$ held more than $20 \%$ of its activity at $50^{\circ} \mathrm{C}$ after $6 \mathrm{~h}$ (Figure 6).

\section{Determination of kinetic parameters}

Effect of substrate concentration on the enzyme catalyzed reaction was studied with increasing concentrations of the substrate. The enzyme reaction followed Michaelis-Menten kinetics and from the initial velocity, the kinetic constants were calculated. The $K_{\mathrm{M}}$ and $V_{\max }$ were $0.147 \mathrm{mM}$ and $814 \mathrm{mmoles} / \mathrm{min} / \mathrm{mg}$ of protein, respectively (Figure 7).

SDS - PAGE analysis has revealed a distinct band with a molecular mass of $42 \mathrm{kDa}$ (Figure 8) which was not visualized in the $\mathrm{YT}_{0}$. This molecular mass found to be nearer to the predicted molecular mass of 42, $668 \mathrm{Da}$ based on the amino acid sequence.

\section{Regulation of recombinant chitinase production in $\mathrm{YT}_{5}$}

The effect of eukaryotic inhibitors was evaluated on growth and chitinase production of the recombinant yeast. The transcriptional inhibitors (8-hydroxyquinoline and 8-azaguanine) inhibited the growth of $\mathrm{YT}_{5}$ significantly $(<20 \%)$ but in the presence of CHI $(100 \mu \mathrm{g} / \mathrm{ml})$, more than $75 \%$ was observed. The protein profile was comparatively reduced to $6 \%$ and $20 \%$ at $100 \mu \mathrm{g} / \mathrm{ml}$ of 8 -hydroxyquinoline and 250 $\mu \mathrm{g} / \mathrm{ml}$ of 8 -azaguanine, respectively when supplemented in the culture medium. Even though relative growth and protein concentrations were reduced in the presence of transcriptional inhibitors, chitinase activity was higher by $70 \%$. In the presence of $\mathrm{CHI}(50 \mu \mathrm{g} / \mathrm{ml})$ the chitinase established $10 \pm 1.06 \%$ of higher activity than the control (Figure 9) but the growth and total protein had not been altered much by CHI (data not shown).

\section{Discussion}

Fungal chitinases, especially from Trichoderma sp. had been cloned and expressed in Escherichia coli. However, the enzyme was produced as inclusion bodies $[29,30]$. In the present experiment, the recombinant chitinase was produced as soluble protein and interestingly almost all the enzyme (99.9\%) was secreted into the culture medium. Recently, a thermophilic fungal chitinase from Paecilomyces thermophila was cloned and expressed in E. coli but the enzyme was reported as soluble protein [31]. Similar to present study, Jinzhu et al. [32] had shown that the T. aureoviridae chitinase was expressed in yeast by pYES2

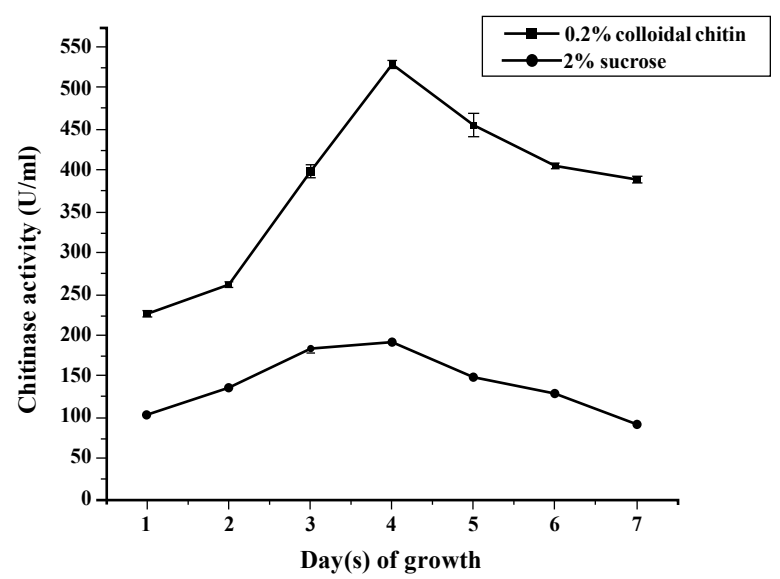

Figure 3:Chitinase activity in $\mathrm{YT}_{5}$ with colloidal chitin and sucrose as inducers.

\begin{tabular}{|c|c|c|c|}
\hline Carbon source & $\begin{array}{c}\text { Growth } \\
\left(\mathbf{A}_{600}\right)\end{array}$ & Protein $(\boldsymbol{\mu g} / \mathbf{m l})$ & $\begin{array}{c}\text { Chitinase activity (U/ } \\
\mathbf{m l})\end{array}$ \\
\hline $0.2 \%$ Colloidal chitin & 0.457 & 56.62 & 456.44 \\
\hline $\begin{array}{c}2 \% \text { Glucose + 0.2\% } \\
\text { Colloidal chitin }\end{array}$ & 1.327 & 6.97 & 7.97 \\
\hline $2 \%$ Glucose & 0.699 & 0.87 & 8.60 \\
\hline
\end{tabular}

Table 1: Effect of glucose on the production of recombinant chitinase in $\mathrm{YT}_{5}$. 
Citation: Prasad M, Palanivelu P (2012) Overexpression of a Chitinase Gene from the Thermophilic Fungus, Thermomyces lanuginosus in Saccharomyces cerevisiae and Characterization of the Recombinant Chitinase. J Microb Biochem Technol 4: 086-091. doi:10.4172/19485948.1000076

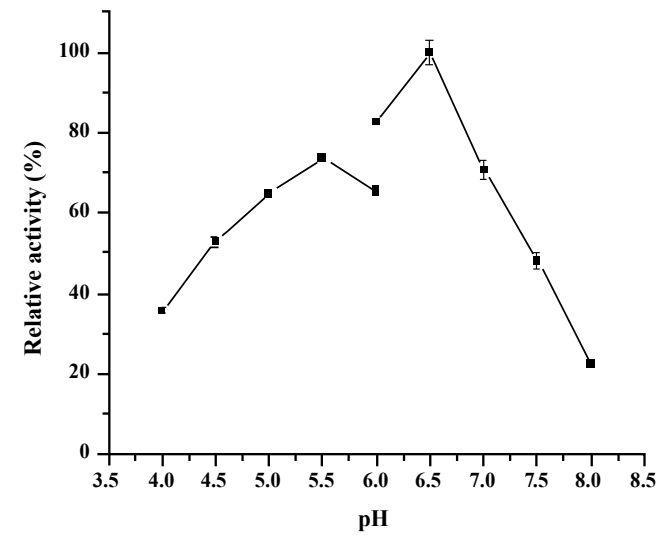

Figure 4: Effect of $\mathrm{pH}$ on the recombinant chitinase activity from $\mathrm{YT}_{5}$. Acetate buffer (0.1M), pH $4.0-6.0$

Na-K Phosphate buffer (0.1M), H 6.0-8.0

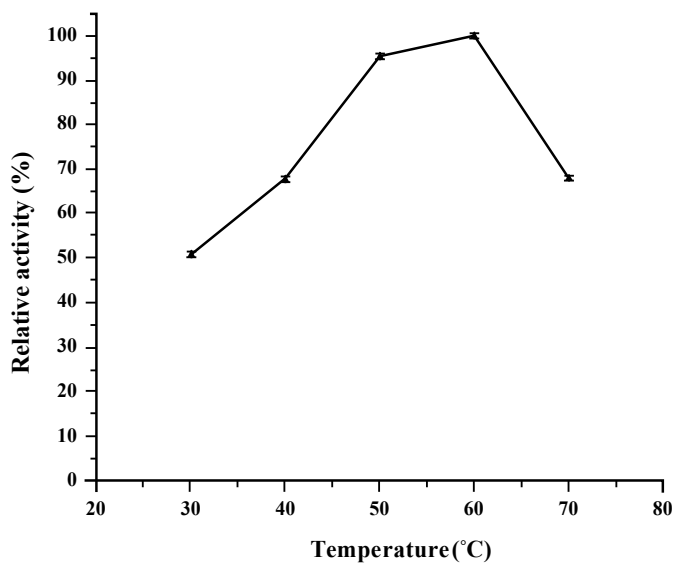

Figure 5: Effect of temperature on the recombinant chitinase activity from $\mathrm{YT}_{5}$.

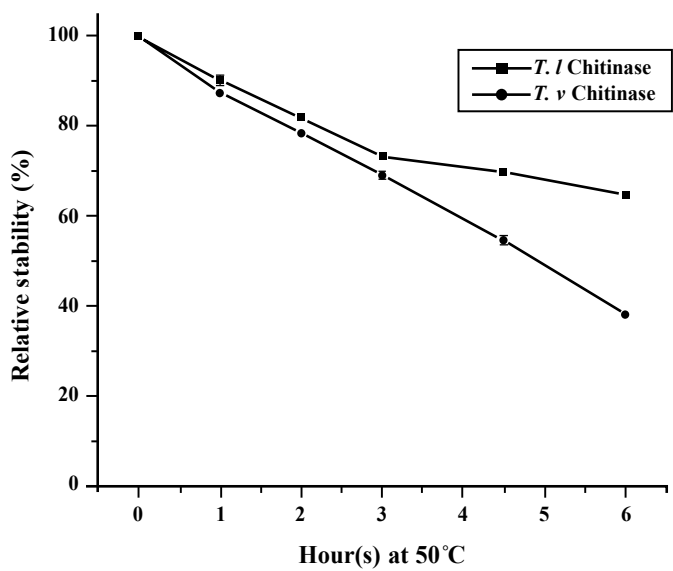

Figure 6: Temperature stability of recombinant chitinase and $T$. viride chitinase

vector under the galactose promoter. The chitinase production from T. harzianum was studied in respect to different substrates in various combinations and the results revealed that maximum production on chitin supplemented medium was found on the seventh day [33]. As reported in Microbispora sp. V2 [17], the $\mathrm{YT}_{5}$ expressed recombinant chitinase maximally on fourth day of the culture. No significant chitinase activity was observed in the $\mathrm{YT}_{0}$ (Figure 2). The chitinase expression was induced with $0.2 \%$ colloidal chitin and similar result was reported by Watanabe et al. [34] on the chitinase expression from Bacillus circulans WL-12 with $0.2 \%$ colloidal chitin and $0.5 \%$ yeast extract.

The recombinant chitinase production was strongly repressed by glucose. Similar results were reported for a chitinase production from T. emersonii [20] and other microbial chitinases [4]. Both sucrose and chitin induced the recombinant chitinase and maximum activity was observed on the fourth day. However, among them, chitin was found to be the better inducer of the chitinase from $\mathrm{YT}_{5}$. This could also be due to stabilization of the recombinant chitinase by the unutilized chitin or its derivatives in the medium.

Many fungal chitinases have an optimum $\mathrm{pH}$ between $\mathrm{pH} 4$ and 8 [35]. Hoell et al. [30] reported that T. atroviride strain P1 chitinase was active from $\mathrm{pH} 3$ to 6 with an optimum of $\mathrm{pH}$ 5.0. Thermococcus chitonophagus chitinase, Chi70 was found to be active in a narrow range of $\mathrm{pH} 6.5$ to 7.5 [8] but the recombinant chitinase from $\mathrm{YT}_{5}$ holds activity in a broad range of $\mathrm{pHs}$ between 4.0 and 8.0 with an optimum activity at $\mathrm{pH} 6.5$ and relatively $50 \%$ of the activity was observed at $\mathrm{pH} 4.5$ and at $\mathrm{pH} 7.5$ which corresponds to the Chaetomium thermophilum thermostable chitinase, CtCHIT1 [22]. The chitinase of T. chitonophagus, Chi70 showed only $50 \%$ activity after $24 \mathrm{~h}$ in the $\mathrm{pH}$ range 3-9 [8], whereas the recombinant chitinase was stable in the $\mathrm{pH}$ ranges from 4.0 to 8.0 for at least 3 weeks at $4^{\circ} \mathrm{C}$.

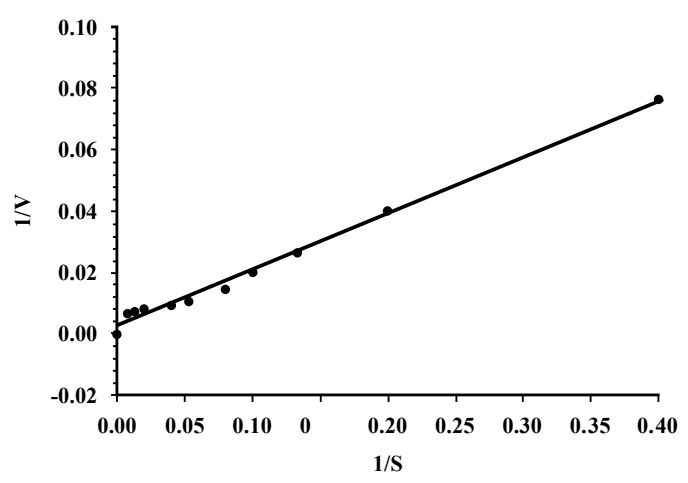

Figure 7: Lineweaver-Bürk plot of the recombinant chitinase from $\mathrm{YT}_{5}$.

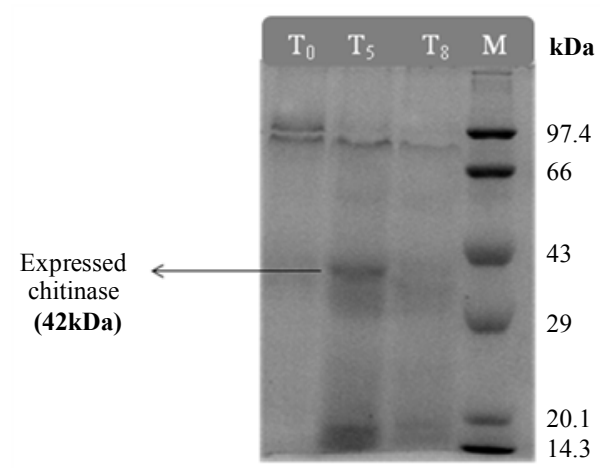

Figure 8: SDS-PAGE analysis of expression of recombinant chitinase from $\mathrm{YT}_{5}$.

Lane 1- Culture filtrate of control $\left(\mathrm{YT}_{0}\right)$, anes $2 \&$ 3- recombinant yeasts ( $\mathrm{YT}$ \& $Y \mathrm{~T}_{8}$ )

Lane M: Protein molecular weight markers. 
Citation: Prasad M, Palanivelu P (2012) Overexpression of a Chitinase Gene from the Thermophilic Fungus, Thermomyces lanuginosus in Saccharomyces cerevisiae and Characterization of the Recombinant Chitinase. J Microb Biochem Technol 4: 086-091. doi:10.4172/19485948.1000076

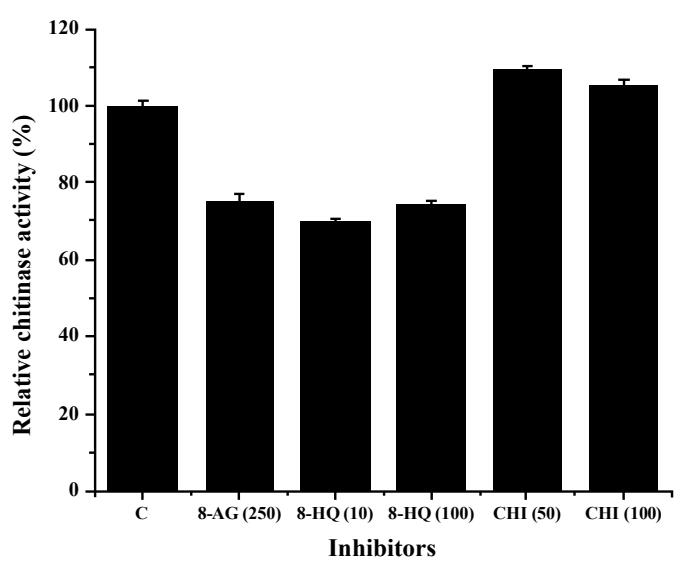

Figure 9: Effect of transcriptional and translational inhibitors on recombinant chitinase production.

C: Control, 8-AG: 8-Azaguanine $(250 \mu \mathrm{g} / \mathrm{ml})$, 8-HQ: 8-Hydroxyquinoline (10 and $100 \mu \mathrm{g} / \mathrm{ml}$ )

$\mathrm{CHI}: 50$ and $100 \mu \mathrm{g} / \mathrm{ml}$

The optimum temperature of the most fungal chitinases represented between 40 and $60^{\circ} \mathrm{C}$. The recombinant chitinase of $\mathrm{YT}_{5}$ was optimally active at $60^{\circ} \mathrm{C}$ which is close to $55^{\circ} \mathrm{C}$ of native chitinase from T. lanuginosus SY2 [21]. Two chitinases from Talaromyces flavus reported with an optimum temperature of $40^{\circ} \mathrm{C}$ showed decreased activity at temperature above $50^{\circ} \mathrm{C}[3]$. The thermostable fungal chitinase from $T$. emersonii had maximum activity at $65^{\circ} \mathrm{C}$ [20]. The optimum temperature of $50^{\circ} \mathrm{C}$ and $60^{\circ} \mathrm{C}$ were reported of T. aurantiacus and C. thermophilum chitinases, respectively [22]. Bacterial thermostable chitinases had optimum temperature between $50^{\circ} \mathrm{C}$ and $60^{\circ} \mathrm{C}[11,17,18]$.

The recombinant chitinase was found to be remarkably stable at $50^{\circ} \mathrm{C}$. The native chitinase from $T$. lanuginosus SY2 was also found to be stable at $50^{\circ} \mathrm{C}$ [21]. Other thermophilic fungal chitinases viz. TaCHIT1 and CtCHIT1 from the thermophilic fungus, T. aurantiacus and $C$. thermophilum, respectively were found to be more stable at higher temperatures [22].

The recombinant chitinase displayed higher substrate affinity with lower $K_{\mathrm{M}}$ value as compared to bacterial chitinases. To exemplify, the chitinase from Pseudomonas aeruginosa strain 385 showed higher $K_{\mathrm{M}}$ value $(4.28 \mathrm{mM})$ with the same substrate [25]. These data showed that the recombinant chitinase is catalytically more efficient for degradation of chitin wastes and chito-oligosaccharides.

According to the amino acid sequence analysis with the chitinase of T. lanuginosus SY2, the recombinant chitinase was found to be truncated protein (data not shown). The molecular weight of the $\mathrm{N}$-terminal truncated recombinant chitinase was found to be $42 \mathrm{kDa}$. The molecular mass of the native chitinase was reported as $48 \mathrm{kDa}$ [21]. However, the truncated protein contained the substrate binding and catalytic domains intact and the N-terminal deletion did not affect the property of the enzyme. Molecular weight of other thermophilic fungal chitinases was also reported in the range of $44-48 \mathrm{kDa}[22,31]$.

The transcriptional inhibitors inhibited the enzyme synthesis with 30\% whereas $\mathrm{CHI}$ had not inhibited the enzyme synthesis significantly. In fact, $10 \%$ higher activity was found than the control, without addition of any inhibitors. But, Ulhoa and Peberdy [36] reported that $T$. harzianum chitinase synthesis was reduced 3 fold by the transcriptional inhibitor, 8 -hydroxyquinoline $(100 \mu \mathrm{g} / \mathrm{ml})$ and 20 fold by CHI $(20 \mu \mathrm{g} / \mathrm{ml})$. However, superinduction phenomenon by $\mathrm{CHI}$ on translation process was reported of CYP1A1 and IL-6 on medium supplemented with $10 \mu \mathrm{g} / \mathrm{ml}$ of $\mathrm{CHI}$ from MCF10A cultures and in intestinal epithelial cells, respectively $[37,38]$. In this study, the ineffectiveness of $\mathrm{CHI}$ could be due to binding of $\mathrm{CHI}$ to the colloidal chitin in the medium because even $10 \mu \mathrm{g} / \mathrm{ml}$ of $\mathrm{CHI}$ inhibits almost completely the growth of the yeast in YEPD medium.

In conclusion, the overexpression of the thermophilic fungal chitinase gene in $S$. cerevisiae has been established. The colloidal chitin was found to be a better inducer for chitinase production. The overexpressed chitinase presents remarkable $\mathrm{pH}$ and thermal stability. Further experiments are in progress for complete analysis of this thermostable chitinase. The recombinant chitinase was very efficient in digesting chitin. These properties of the recombinant chitinase are valuable for the industrial processing of chitin, bioconversion of natural chitin wastes, production of single cell proteins and chitooligosaccharides, enzymatic conversion of chitin to ethanol and other biotechnological applications.

\section{Acknowledgments}

The authors are grateful to University Grants Commission, New Delhi for financial support under UGC-MRP to corresponding author. The authors would like to thank Dr. H. Shakila, Associate professor, School of Biotechnology, Madurai Kamaraj University, for the suggestions on the manuscript.

\section{References}

1. Aam BB, Heggset $E B$, Norberg AL, Sorlie M, Varum KM, et al. (2010) Production of chitooligosaccharides and their potential applications in medicine. Mar Drugs 8: $1482-1517$

2. Henrissat B, Bairoch A (1993) New families in the classification of glycosy hydrolases based on amino acid sequence similarities. Biochem J 293: 781 788

3. Duo-Chuan LI, Chen S, Jing LU (2005) Purification and partial characterization of two chitinases from the mycoparasitic fungus Talaromyces flavus. Mycopathologia 159: 223-229.

4. Felse PA, Panda T (1999) Regulation and cloning of microbial chitinase genes Appl Microbiol Biotechnol 51: 141-151.

5. Demirjian DC, Moris-varas F, Cassidy CS (2001) Enzymes from extremophiles Curr Opin Chem Biol 5: 144-151.

6. Becker P, Abu-Reesh I, Markossian S, Antranikian G, Markl H (1997) Determination of the kinetic parameters during continuous cultivation of the lipase-producing thermophile Bacillus sp. IHI-91 on olive oil. Appl Microbiol Biotechnol 48: 184-190.

7. Aranaz I, Mengíbar M, Harris R, Panos I, Miralles B, et al. (2009) Functional characterization of chitin and chitosan. Curr Chem Bio 3: 203-230.

8. Andronopoulou E, Vorgias CE (2003) Purification and characterization of a new hyperthermostable, allosamidin-insensitive and denaturation-resistant chitinase from the hyperthermophilic archaeon Thermococcus chitonophagus. Extremophiles 7: 43-53.

9. Imanaka T, Fukui T, Fujiwara S (2001) Chitinase from Thermococcus kodakaraensis KOD1. Methods Enzymol 330: 319-329.

10. Gao J, Bauer MW, Shockley KR, Pysz MA, Kelly RM (2003) Growth of hyperthermophilic archaeon Pyrococcus furiosus on chitin involves two family 18 chitinases. Appl Environ Microbiol 69: 3119-3128.

11. Lien TS, Yu ST, Wu ST, Too JR (2007) Induction and purification of a thermophilic chitinase produced by Aeromonas sp. DYU-too7 using glucosamine. Biotechnol and Bioprocess Eng 12: 610-617.

12. Sakai K, Yokota A, Kurokawa H, Wakayama M, Moriguchi M (1998) Purification and characterization of three thermostable endochitinases of a noble Bacillus strain, $\mathrm{MH}-1$, isolated from chitin-containing compost. Appl Environ Microbiol 64: 3397-3402 
Citation: Prasad M, Palanivelu P (2012) Overexpression of a Chitinase Gene from the Thermophilic Fungus, Thermomyces lanuginosus in Saccharomyces cerevisiae and Characterization of the Recombinant Chitinase. J Microb Biochem Technol 4: 086-091. doi:10.4172/19485948.1000076

13. Bhushan B (2000) Production and characterization of a thermostable chitinase from a new alkalophilic Bacillus sp. BG-11. J Appl Microbiol 88: 800-808

14. Waghmare SR, Ghosh JS (2010) Chitobiose production by using a novel thermostable chitinase from Bacillus licheniformis strain JS isolated from a mushroom bed. Carbohydr Res 345: 2630-2635.

15. Cho EK, Choi IS, Choi YJ (2011) Overexpression and characterization of thermostable chitinase from Bacillus atrophaeus SC081 in Escherichia coli. BMB Rep 44: 193-198.

16. Zverlov VV, Fuchs KP, Schwarz WH (2002) Chi18A, the endochitinase in the cellulosome of the thermophilic, cellulolytic bacterium Clostridium thermocellum. Appl Environ Microbiol 68: 3176-3179.

17. Nawani NN, Kapadnis BP, Das AD, Rao AS, Mahajan SK (2002) Purification and characterization of a thermophilic and acidophilic chitinase from Microbispora sp. V2. J Appl Microbiol 93: 965-975.

18. Singh AK (2010) Optimization of culture conditions for thermostable chitinase production by Paenibacillus sp. D1. Afr J Microbiol Res 4: 2291-2298.

19. Tsujibo H, Minoura K, Miyamoto K, Endo H, Moriwaki M, et al. (1993) Purification and properties of a thermostable chitinase from Streptomyces thermoviolaceus OPC-520. Appl Environ Microbiol 59: 620-622.

20. McCormack J, Thomas HJ, Maria TG, Michael CP (1991) Chitinase production by Talaromyces emersonii. Biotechnol Lett 13: 677-682.

21. Guo RF, Shi BS, Li DC, Ma W, Wei Q (2008) Purification and characterization of a novel thermostable chitinase from Thermomyces lanuginosus SY2 and cloning of its encoding gene. Agric Sci China 7: 1458-1465.

22. Li A, Yu K, Liu H, Zhang J, Li H, et al. (2010) Two novel thermostable chitinase genes from thermophilic fungi: cloning, expression and characterization. Bioresour Technol 101: 5546-5551.

23. Delgado ML, Gil ML, Gozalbo D (2003) Candida albicans TDH3 gene promotes secretion of internal invertase when expressed in Saccharomyces cerevisiae as a glyceraldehyde-3 phosphate dehydrogenase-invertase fusion protein. Yeast 20: 713-722.

24. Sandhya C, Adapa LK, Nampoothiri KM, Binod P, Szakacs G, et al. (2004) Extracellular chitinase production by Trichoderma harzianum in submerged fermentation. J Basic Microbiol 44: 49-58.

25. Thompson SE, Smith M, Wilkinson MC, Peek K (2001) Identification and characterization of a chitinase antigen from Pseudomonas aeruginosa strain 385. Appl Environ Microbiol 67: 4001-4008.

26. Chernin LS, Winson MK, Thompson JM, Haran S, Bycroft BW, et al. (1998) Chitinolytic activity in Chromobacterium violaceum: substrate analysis and regulation by quorum sensing. J Bacteriol 180: 4435-4441.
27. Bradford MM (1976) A rapid and sensitive method for the quantitation of microgram quantities of protein utilizing the principle of protein-dye binding Anal Biochem 72: 248-254.

28. Laemmli UK (1970) Cleavage of structural proteins during the assembly of the head of bacteriophage T4. Nature 227: 680-685.

29. Alias N, Mahadi MN, Murad AMA, Bakar FDA, Mahmood NAN, et al. (2009) Expression and characterization of Trichoderma virens UKM-1endochitinase in Escherichia coli. World J Microbiol Biotechnol 25: 561-572.

30. Hoell IA, Klemsdalb SS, Vaaje-Kolstada G, Horn SJ, Eijsink VG (2005) Overexpression and characterization of a novel chitinase from Trichoderma atroviride strain P1. Biochim Biophys Acta 1748: 180-190.

31. Kopparapu NK, Zhou P, Zhang S, Yan Q, Liu Z, et al. (2012) Purification and characterization of a novel chitinase gene from Paecilomyces thermophila expressed in Escherichia coli. Carbohydr Res 347: 155-160.

32. Jinzhu S, Qian Y, Beidong L, Dianfu C (2005) Expression of the chitinase gene from Trichoderma aureoviride in Saccharomyces cerevisiae. Appl Microbio Biotechnol 69: 39-43

33. El-Katatny MH, Somitsch W, Robra KH, El-Katatny MS, Gubitz GM (2000) Production of chitinase and $\beta$-1,3-glucanase by Trichoderma harzianum for control of the phytopathogenic fungus, Sclerotium rolfsii. Food Techno Biotechnol 38: 173-180.

34. Watanabe T, Oyanagi W, Suzuki K, Tanaka H (1990) Chitinase system of Bacillus circulans WL-12 and importance of chitinase A1 in chitin degradation. J Bacteriol 172: 4017-4022.

35. Sahai AS, Manocha MS (1993) Chitinases of fungi and plants: their involvement in morphogenesis and host-parasite interaction. FEMS Microbiol Rev 11: 317 338

36. Ulhoa CJ, Peberdy JF (1991) Regulation of chitinase synthesis in Trichoderma harzianum. J Gen Microbiol 137: 2163-2169.

37. Joiakim A, Mathieu PA, Elliott AA, Reiners JJ Jr. (2004) Superinduction of CYP1A1 in MCF10A cultures by cycloheximide, anisomycin and puromycin: a process independent of effects on protein translation and unrelated to suppression of aryl hydrocarbon receptor proteolysis by the proteasome. Mo Pharmacol 66: 936-947.

38. Hershko DD, Robb BW, Wray CJ, Luo GJ, Hasselgren P (2004) Super induction of IL- 6 by cycloheximide is associated with mRNA stabilization and sustained activation of p38 map kinase and NF-kappaB in cultured caco-2 Cells. J Cell Biochem 91: 951-961. 